\title{
Invitro Evaluation of Sea Weed Extracts and Bio-control Agent against Rhizoctonia solani causing Rice Sheath Blight Disease
}

\author{
D. Anandeeswari* and D. John Christopher \\ Department of Plant pathology, Faculty of Agriculture, Annamalai University, \\ Annamalai Nagar- 608002 (T.N.) India \\ *Corresponding author
}

\begin{abstract}
A B S T R A C T
Rice (Oryza sativa L.) is an important staple food crop for majority of the world. Many biotic stresses hamper rice production and specifically, fungal diseases cause huge economic losses. Among different fungal disease of rice sheath blight caused by Rhizoctonia solani Kuhn is emerging as a very destructive disease and it is an important one responsible for losses in grain yield. Diseases management is currently focused on extensive use of fungicides which has created concerns about environmental pollution, pathogen résistance and escalating costs. The present study focused on the effect of various seaweeds extracts and biocontrol agents on controlling sheath blight in rice caused by R.solani under in vitro condition. Use of biocontrol agents and sea weed extracts is an eco friendly, cost effective and sustainable alternative method in disease management. Ten isolates of Pseudomonas fluorescens obtained from rice rhizosphere were tested against $R$. solani. Among these isolates Pf- 5 was effectively inhibited the mycelial growth in dual culture tests was recorded 75.84 , mycelial dry weight was recorded $146.00 \mathrm{mg} / 50 \mathrm{ml} / \mathrm{broth}$, minimum mycelial growth was recorded $12.54 \mathrm{~mm}$ at $20 \%$ conc. and maximum germination percentage, Shoot and root length, Plant vigour index was recorded 97.21, 9.12 and $18.23 \mathrm{~cm}, 2658.69$. It was followed by the Pf- 3 isolate. Seven different sea weeds such as Sargassum wightii, Padina tetrastromatica, Gracillaria corticata, Chondrococcus hornemanii, Ulva lactuca, Enteromorpha intensalis, Enteromorpha compressa were tested against R.solani was carried out by Poisoned food technique, Paper disc and Agar well method. Among the extracts, Sargassum wightii at the highest concentration (20\%) was found to be minimum mycelial growth was recorded $12.66 \mathrm{~mm}$ and maximum reduction was recorded 42.58 and $43.29 \mathrm{~mm}$.
\end{abstract}

\section{Keywords}

Rice, $R$. solani, Sea weed extracts, P.fluorescens, Antifungal activity

\section{Article Info}

Accepted:

07 August 2020

Available Online:

10 September 2020

\section{Introduction}

Rice (Oryza sativa L.) is one of the important food crop of the world both in terms of area $163.7 \mathrm{~m}$ ha and production $749.8 \mathrm{~m}$ tones. About 90 per cent of the world wide is grown and consumed in Asia and 60 per cent of world population were depends on the rice for their half of the calorie intake (FAO, Rice market monitor, 2015). Rice cultivation is often subjected to several biotic stresses of diseases like Sheath blight, Sheath rot, Blast, Brown leaf spot and Bacterial blight which are the important ones. Among different 
fungal diseases of rice, Sheath blight caused by Rhizoctonia solani Kuhn is emerging as a destructive disease. Management of this disease is difficult due to viability of sclerotia in the soil for several year. Many method of plant disease control are presently being used to control the rice sheath blight disease, such as physical, chemical and cultural methods. Use of fungicides to control the diseases causes several adverse effect i.e, Development of resistance in the pathogen, Residual toxicity, Pollution in environment, High cost etc..,

The organic control of soil borne pathogens is a potential alternative to the use of chemicals (Rathore et al., 2009). Marine products as sea weed provide a rich source of structurally diverse and biologically active secondary metabolites (Jeffrey Norrie et al., 2014; Suthin raj et al., 2016). The function of these secondary metabolites are defense mechanism against herbivores, fouling organisms and pathogens (Ammirato, 1986; Suthin raj et al., 2016). Application of sea weeds extracts is proved to be better to decrease the foliar fungal diseases which ultimately increases its fertility and help the growth of plants (Jayaraj et al., 2008).Besides effective management strategy of Sheath blight disease is feasible only when biocontrol agents in rice based cropping system survive, establish, proliferate and control sheath blight pathogen and also have a synergistic growth promoting effect on the crop. Biocontrol agents induce systemic resistance thereby contributing to disease control. Bacteria isolate from rice seeds and rice eco-system were able to effectively suppress sheath blight besides producing growth promoting effects. Seed treatments with antagonistic bacteria resulted in increased root and shoot length of seedling. Foliar sprays with these antagonistic agents results in reduced sheath blight incidence (Sharma et al., 2004). Hence, in the present study some biocontrol agents and marine products from locally available were tested in-vitro against R.solani.

\section{Materials and Methods}

\section{Isolation of pathogen}

The diseased rice plant showing the typical symptom of sheath blight disease were collected. The infected portion of the sheath was cut into small bits, surface sterilized into 0.1 per cent mercuric chloride solution for 30 sec washed in repeated changes of sterile distilled water and plated into PDA medium in sterilized Petri dishes. The plates were incubated for room temperature $\left(28 \pm 2^{\circ} \mathrm{C}\right)$ for five days and were observed the fungal growth.

\section{Purification}

Prepare and pour warm plain agar $(2 \%)$ in a Petri plate. Inoculate the mixture culture in the centre of the plate. Incubate at room temperature. Invert the plate and examine under the microscope for hyphal tip in the periphery of the plate. Cut the hyphal tip area along with some medium using a cork borer. Transfer medium to agar slant with the help of inoculation needle. Incubate culture at room temperature for 2 to 3 days by single hyphal tip method.

\section{Isolation of Bacterial antagonists (Kings et al., 1954)}

Several strains of P.fluorescens were isolated from the rhizosphere soil of healthy rice cultivating fields. Add one $\mathrm{g}$ of rhizosphere soil in $10 \mathrm{ml}$ of distilled water and shake it for 5 mins and prepare serial dilution. Transfer one $\mathrm{ml}$ each of dilution to plate. Pour melted and cooled king's B medium. Incubate the plates at $28^{\circ} \mathrm{C}$ for $48 \mathrm{hrs}$. Pseudomonas colonies on the selective medium will be greenish blue (or) dark colonies. 


\section{Purification}

Prepare and pour warm nutrient agar in a plate. Touch mixed bacterial culture with inoculation loop and take the culture. Make a series of parallel non-overlapping streaks on the nutrient agar plate. Incubate culture at room temperature for 24 hours by using streak plate method.

\section{Evaluation of Bacterial antagonist against R. solani in-vitro}

\section{Dual culture technique (Dennis and Webster, 1971)}

P.fluorescens was multiplied in King's B medium. An $9 \mathrm{~mm}$ actively growing PDA culture disc of the pathogen was placed on PDA medium in sterilized Petri dish at one side and actively growing 48-h- old culture of respective test bacteria were separately streaked onto the medium at the opposite side of the plate, $1.5 \mathrm{~cm}$ away from the edge of the plate. The inoculated plates were incubated at room temperature $28 \pm 2{ }^{\circ} \mathrm{C}$. Three replications were maintained for each antagonists. Potato dextrose agar medium inoculated with the pathogen alone served as control. After $48 \mathrm{hrs}$, the radial growth of the pathogens was measured. The results were expressed as per cent growth inhibition over control (Vincent., 1927).

$\mathrm{I}=\mathrm{C}-\mathrm{T} / \mathrm{C} \mathrm{x} 100$

Where, $\mathrm{I}=$ inhibition per cent, $\mathrm{C}=$ radial growth in control and $\mathrm{T}=$ radial growth in treatment.

\section{Mycelia dry weight}

Potato dextrose broth was prepared in $250 \mathrm{ml}$ conical flasks and autoclaved. Culture filtrates of P.fluorescens was added to 45, 40, 35 and $30 \mathrm{ml}$ broth in flasks so as to get the final concentration of 10, 20, 30 and 40 per cent of the filtrate in the broth. All the flasks were inoculated with $9 \mathrm{~mm}$ cultures discs of pathogens ( $R$. solani) and incubated $28 \pm 1{ }^{\circ} \mathrm{C}$ for 10 days. Broth without any filtrate serves as control. Three replications were maintained for each treatment. After the incubation period. The mycelia mat was harvest on a previously weighed filter paper and dried at $105^{\circ} \mathrm{C}$ for $12 \mathrm{~h}$ in a hot air oven, cooled in a dessiccator and the mycelia weight was recorded expressed at $\mathrm{mg} / 50 \mathrm{ml} / \mathrm{broth}$.

\section{Preparation of culture filtrates of bacterial antagonist}

The effective P.fluorescens isolate were inoculated into Erlenmeyer flasks containing $100 \mathrm{ml}$ of sterilized King's B broth then kept on a rotary shaker at $100 \mathrm{rpm}$ for $48 \mathrm{hrs}$. then the cultures were filtered through a bacteriological filter under vaccum and the filtrates thus obtained were used for further studies.

\section{Effect of culture filtrates on the mycelia growth of $R$. solani}

The culture filtrate of the antagonists were separately incorporated into sterilized PDA media at 5,10, 15 and 20 per cent by adding the calculated quantity of the culture filtrates to the medium by means of a sterile pipette. The PDA medium without the culture filtrate served as control.

The amended media were transferred to sterile petri plates separately @ $15 \mathrm{ml}$ and allowed to solidify. Each plate was inoculated at the center with five days old culture disc of $R$. solani. Three replication were maintained for each treatment. The diameter of the mycelia growth of $R$. solani was measured when the mycelial growth fully covered the control plates. 


\section{Plant growth promotion}

Plant growth promoting activity of the antagonists was assessed based on the seedling vigour index by the standard roll towel method (ISTA 1976). Paddy seeds were surface sterilized with two per cent sodium hypochloride for $30 \mathrm{sec}$ rinsed in sterile distilled water and then soaked in $10 \mathrm{ml}$ antagonistic suspension for $2 \mathrm{hrs}$ and then dried. Seeds were kept over the pre- soaked germination paper. The seeds were held in position by placing another pre - soaked germination paper strip over it and gently pressed. The sheets along with seed were then rolled and incubated in growth chamber for 10 days. Three replications were maintained for each treatment. The root length and shoot length of individual seedling were measured and the per cent germination of seeds was also calculated. The seedling vigour index was calculated by using the formula as described by (Abdul Baki and Anderson, 1973).

Vigour index $=($ Mean root length + Mean shoot length) $\mathrm{X}$ germination (\%)

Based on the results of the above studies, the most effective isolate of $P$. fluorescens were tested for the compatibility for the preparation of a combination of formulation.

Evaluation of marine products against $R$. solani in vitro

\section{Collection of Seaweeds}

The seaweeds Ulva lactuca, Enteromorpha compressa, Enteromorpha intensalis Sargassum wightii, Padina tetrastromatica, Gracillaria corticata, Chondrococcus homemanii were collected from Mandapam coast, Tamil Nadu. The seaweeds were handpicked and washed thoroughly with seawater to remove the unwanted impurities, adhering sand particles and epiphytes. They were transported to the laboratory in polythene bags. Samples were washed thoroughly using tap water to remove salt the surface salt and then blotted to remove excess water.

\section{Preparation of Seaweed extract}

Seaweeds were shade dried for four days, followed by oven dry for $12 \mathrm{~h}$ at $60^{\circ} \mathrm{C}$. Then the materials were hand crushed and made as coarse powder was added with distilled in a ratio of 1: $20(\mathrm{w} / \mathrm{v})$ and autoclaved at $121^{\circ} \mathrm{C}$, $15 \mathrm{lbs} / \mathrm{sq}$. inch for 30 minutes. The hot extracts were filtered through a double-layered cheese cloth and allowed to cool at room temperature (Rama Rao, 1990). The filtrate was centrifuged at 10,000rpm for 15 minutes. The resulting supernatant was taken as $100 \%$ seaweed liquid extracts. Seaweed liquid extracts were prepared with different doses viz., $5 \%, 10 \%, 15 \%$ and $20 \%$.

\section{Evaluation of Marine products against R.solani}

\section{Poisoned food technique}

Seven seaweeds, Sargassum wightii, Padina tetrastromatica, Gracillaria corticata, Chondroccocus homemanii, Ulva lactuca, Entromorpha intensalis, Enteromorpha compressa were used for the study. The effect of various sea weeds on the radial growth of the pathogen was studied by Poisoned food technique (Schmitz, 1930). Required quantity of sea weeds extracts were mixed with autoclaved and cooled PDA just before pouring into Petri dishes, so as to obtain the required concentrations viz.,5\%, $10 \%, 15 \%$, $20 \%$. The medium was then dispensed uniformly into $90 \mathrm{~mm}$ diameter Petri plates and inoculated with $9 \mathrm{~mm}$ mycelia disc of the pathogen from 7 days old culture with their mycelial disc side down. Pathogen inoculated 
in unamended medium served as control. The growth of the fungus was monitored by measuring the radial growth in $\mathrm{mm}$ every each till the fungus covers the plates completely in control plates. The per cent inhibition (PI) of the fungus over control was calculated using the following formulae.

$\mathrm{PI}=(\mathrm{A}-\mathrm{B}) / \mathrm{A} \times 100$

Where, $\mathrm{A}$ is colony diameter of the fungus in control plates $(\mathrm{mm})$ and $\mathrm{B}$ is colony diameter of the fungus in treated plates ( $\mathrm{mm})$.

\section{Agar well method (Thongson et al., 2004)}

Sea weed extracts like 5\%, 10\%, 15\%, 20\% individually were added to the sterilized potato dextrose agar medium and thoroughly mixed just before plating. These mixtures individually were immediately poured into sterilized Petri plates and were allowed to solidify. A $9 \mathrm{~mm}$ of PDA disc was removed by using cork borer to form wells. $1 \mathrm{ml}$ of spore suspension was poured into well. All these were carried out under aseptic conditions. The plates were incubated at $28 \pm 2^{\circ} \mathrm{C}$ for 10 days. Potato dextrose agar medium without marine products served as the control. Three replications were maintained. the radial growth of the colony was measured. The per cent inhibition of the growth was calculated.

\section{Paper disc method (Saha et al., 1995)}

The desired concentration of seaweed extracts were incorporated into sterile filter paper discs $(5 \mathrm{~mm}$ dia). The incorporated extract discs were placed on seeded agar plates and incubated at room temperature $28 \pm 2^{\circ} \mathrm{C}$. Three replications were maintained for each treatment. The inhibition zone of fungal growth around the treated sterile filter paper discs was measured and recorded.

\section{Results and Discussion}

\section{In-vitro evaluation of $\boldsymbol{P}$. fluorescens against R.solani}

Ten isolates of $P$. fluorescens were isolated and tested their efficacy against R.solani presented in Table 1. Among these isolates $P f-5$ was appear to be most effective against the test pathogen showing 75.84 per cent inhibition of colony growth by dual culture technique. It was followed by isolates $P f-3$ showing 73.83 per cent inhibition, which statistical on par each other. The isolates $P f-8$ and $P f-4$ gave minimum growth inhibition. All the isolates significantly reduced the mycelial growth of the pathogen over the control. The mycelial dry weight of the pathogen was also recorded on 10, 20, 30, 40 per cent concentration of culture filtrates of antagonists. All the treatments were effective to reduce the growth of the pathogen. However the treatmentsPf-5 was maximum reduced the growth of $146.00 \mathrm{mg} / 50 \mathrm{ml} /$ broth at 10, 20, 30, 40 per cent concentration (Table 1 ). Ten different isolates of $P$. fluorescens were screened at various concentrations against R.solani and the results are presented in (Table 2) were significantly superior in their efficacy over the control. Among the antagonists effective $P f$ - 5 at conc. $20 \%$ was recorded in $12.54 \mathrm{~mm}$. It was followed by isolates $P f-3$ showing $15.10 \mathrm{~mm}$. The isolates $P f-8$ and $P f-4$ was found to be least effective against $R$. solani. The effect of culture filtrates of the $P$. fluorescens on paddy seed germination and growth promotion are presented in (Table 3). The culture filtrates of none of the isolates showed any inhibitory effect on the germination of paddy seeds and in general all the isolates induced plant growth promotion viz., shoot and root length significantly over untreated check as revealed by the data. Among the isolates tested $P f-5$ isolate recorded a maximum germination per cent of 97.21 and also increased the shoot and 
root length of 9.12 and $18.23 \mathrm{~cm}$ respectively with a vigour index of 2658.69. it was followed by the isolates $P f-3$. The rest of the isolates also significantly increased the shoot and root length with the exception of the control which recorded the lowest shoot and root length of 4.56 and $10.05 \mathrm{~cm}$. This may be due to the production of an array of antifungal antibiotics such as 2, 4 - diacetylphophloglucinol, Oligomycin, Phenazine, Pyoluteorin, Pyrlnitrin and Pyocyanin by $P$. flourescens (Gupta et al., 2001). A similar result was observed by several workers (Seema and Devaki., 2012 and Sryadi et al., 2013).

Similarly, antifungal compounds such as Pseudobactin, HCN, Salicylic acid and 2hydroxyl Phenazine produced by Flourescent psedomonads suppressed plant pathogenic fungi (Ongena et al., 1999; Velazhahan et al., 1999; Gupta et al., 2001; Pandey et al., 2006 and Reddy et al., 2008).
In-vitro evaluation of marine products against $R$.solani

In present study seven sea weed were tested against R.solani and presented in Table 4. All the tested sea weeds registered appreciable inhibition in colony growth. Among seven sea weeds Sargassum wightii at a highest concentration (20\%) was fond to be the maximum was recorded 12.66 percent inhibiting the mycelial growth of R.solani by poisoned food technique. sea weeds extracts were selected and evaluated for the antimicrobial activity by paper disc and agar well method. The extract of Sargassum wightii at a highest concentration (20\%) was found to be the maximally reduced in paper disc and agar well method was recorded 42.58 and 43.29 per cent inhibition zone respectively. It was followed by a highest concentration (20\%) of Padina tetrastromatica which recorded 39.71 and 41.95per cent inhibition (Table 5).

Table1 Evaluation of various isolates of $P$. fluorescens against $R$. solani

\begin{tabular}{|c|c|c|c|c|c|c|c|c|}
\hline \multirow[b]{2}{*}{ Isolates } & \multicolumn{3}{|c|}{ Dual culture (R. solani) } & \multicolumn{5}{|c|}{ Mycelial dry weight (mg/ml/broth) } \\
\hline & Antagonists & $\begin{array}{c}\text { Mycelial } \\
\text { growth }(\mathrm{mm})\end{array}$ & $\begin{array}{c}\text { Percent } \\
\text { inhibition } \\
\text { over control }\end{array}$ & $10 \%$ & $20 \%$ & $30 \%$ & $40 \%$ & Mean \\
\hline $\mathbf{P f}_{1}$ & $60.30^{c}$ & $29.70^{\mathrm{g}}$ & 67.00 & $305^{\mathrm{f}}$ & $245^{\mathrm{f}}$ & $137^{\mathrm{f}}$ & $38^{\mathrm{f}}$ & 181.25 \\
\hline $\mathbf{P f}_{2}$ & $57.14^{\mathrm{d}}$ & $32.86^{\mathrm{f}}$ & 63.48 & $323^{\mathrm{e}}$ & $253^{f}$ & $144^{\mathrm{f}}$ & $42^{f}$ & 190.50 \\
\hline $\mathbf{P f}_{3}$ & $66.45^{\mathrm{a}}$ & $23.55^{1}$ & 73.83 & $272^{\mathrm{g}}$ & $220^{\mathrm{h}}$ & $106^{\mathrm{h}}$ & $29^{\mathrm{g}}$ & 156.75 \\
\hline $\mathbf{P f}_{4}$ & $46.73^{\mathrm{h}}$ & $43.27^{b}$ & 51.92 & $382^{\mathrm{ab}}$ & $298^{\mathrm{b}}$ & $197^{\mathrm{b}}$ & $63^{\mathrm{b}}$ & 235.00 \\
\hline $\mathbf{P f}_{5}$ & $68.26^{\mathrm{a}}$ & $21.74^{1}$ & 75.84 & $258^{\mathrm{g}}$ & $207^{1}$ & $198^{b}$ & $21^{\mathrm{h}}$ & 146.00 \\
\hline $\mathbf{P f}_{6}$ & $55.50^{\mathrm{de}}$ & $34.50^{\mathrm{ef}}$ & 61.66 & $345^{\mathrm{d}}$ & $267^{\mathrm{e}}$ & $156^{\mathrm{e}}$ & $47^{\mathrm{e}}$ & 203.75 \\
\hline $\mathbf{P f}_{7}$ & $63.15^{\mathrm{b}}$ & $26.85^{\mathrm{h}}$ & 70.16 & $291^{\mathrm{f}}$ & $234^{\mathrm{g}}$ & $123^{g}$ & $33^{g}$ & 170.25 \\
\hline $\mathbf{P f}_{8}$ & $49.80^{\mathrm{g}}$ & $40.20^{c}$ & 55.33 & $375^{\mathrm{ab}}$ & $289^{b c}$ & $182^{c}$ & $59^{\mathrm{bc}}$ & 226.25 \\
\hline $\mathbf{P f}_{9}$ & $53.91^{\text {ef }}$ & $36.09^{\mathrm{de}}$ & 59.90 & $351^{\mathrm{cd}}$ & $271^{\mathrm{de}}$ & $163^{\text {de }}$ & $51^{\mathrm{de}}$ & 209.00 \\
\hline $\mathbf{P f}_{10}$ & $52.18^{f}$ & $37.82^{d}$ & 57.97 & $367^{\mathrm{bc}}$ & $280^{\mathrm{cd}}$ & $171^{\mathrm{d}}$ & $55^{\mathrm{cd}}$ & 222.00 \\
\hline Control & - & $90.00^{\mathrm{a}}$ & - & $390^{\mathrm{a}}$ & $390^{\mathrm{a}}$ & $390^{\mathrm{a}}$ & $390^{\mathrm{a}}$ & 390.00 \\
\hline $\begin{array}{c}\text { CD } \\
(p=0.05)\end{array}$ & 2.08 & 1.94 & & 17.57 & 10.22 & 9.75 & 4.95 & \\
\hline
\end{tabular}

*Values are means of three replications. In a column, means followed by a common letter are not significantly different at $5 \%$ level by DMRT's 
Table.2 Effect of $P$. fluorescens isolates on mycelia growth of $R$. solani (Poisoned food technique)

\begin{tabular}{|c|c|c|c|c|c|c|c|c|}
\hline \multirow[b]{2}{*}{ Isolates } & \multicolumn{8}{|c|}{ Mycelial growth (mm) } \\
\hline & $5 \%$ & $\begin{array}{c}\text { Percent } \\
\text { inhibition } \\
\text { over } \\
\text { control }\end{array}$ & $10 \%$ & $\begin{array}{c}\text { Percent } \\
\text { inhibition } \\
\text { over } \\
\text { control }\end{array}$ & $15 \%$ & $\begin{array}{c}\text { Percent } \\
\text { inhibition } \\
\text { over } \\
\text { control }\end{array}$ & $20 \%$ & $\begin{array}{c}\text { Percent } \\
\text { inhibition } \\
\text { over control }\end{array}$ \\
\hline $\mathbf{P f}_{1}$ & $48.34^{\mathrm{g}}$ & 46.28 & $42.14^{\mathrm{h}}$ & 53.17 & $36.76^{\mathrm{h}}$ & 59.15 & $20.98^{\mathrm{h}}$ & 76.68 \\
\hline $\mathbf{P f}_{2}$ & $52.89^{f}$ & 41.23 & $45.67^{\mathrm{g}}$ & 49.25 & $39.32^{\mathrm{g}}$ & 56.31 & $23.45^{\mathrm{g}}$ & 73.94 \\
\hline $\mathbf{P f}_{3}$ & $39.12^{\mathrm{i}}$ & 56.53 & $36.46^{\mathrm{j}}$ & 59.48 & $28.67^{\mathrm{j}}$ & 68.14 & $15.10^{\mathrm{j}}$ & 83.22 \\
\hline $\mathbf{P f}_{4}$ & $71.09^{b}$ & 21.01 & $63.78^{\mathrm{b}}$ & 2913 & $59.43^{\mathrm{b}}$ & 33.96 & $39.12^{\mathrm{b}}$ & 56.53 \\
\hline $\mathbf{P f}_{5}$ & $37.89^{\mathrm{i}}$ & 57.90 & $30.13^{\mathrm{k}}$ & 66.52 & $22.34^{\mathrm{k}}$ & 75.17 & $12.54^{\mathrm{k}}$ & 86.06 \\
\hline $\mathbf{P f}_{6}$ & $56.22^{\mathrm{e}}$ & 37.53 & $48.57^{f}$ & 46.03 & $43.79^{f}$ & 51.34 & $27.24^{\mathrm{f}}$ & 69.73 \\
\hline $\mathbf{P f _ { 7 }}$ & $43.70^{\mathrm{h}}$ & 51.44 & $39.98^{\mathrm{i}}$ & 55.57 & $32.25^{\mathrm{i}}$ & 64.16 & $18.89^{\mathrm{i}}$ & 79.01 \\
\hline $\mathbf{P f}_{8}$ & $69.89^{b}$ & 22.34 & $60.32^{c}$ & 32.97 & $57.23^{c}$ & 36.41 & $37.76^{\mathrm{c}}$ & 58.04 \\
\hline $\mathbf{P f}_{9}$ & $59.31^{\mathrm{d}}$ & 34.10 & $54.90^{\mathrm{e}}$ & 39.00 & $47.52^{\mathrm{e}}$ & 47.20 & $32.53^{\mathrm{d}}$ & 63.85 \\
\hline $\mathbf{P f}_{10}$ & $63.56^{c}$ & 29.37 & $56.67^{d}$ & 37.03 & $51.91^{d}$ & 42.32 & $35.25^{\mathrm{c}}$ & 60.83 \\
\hline Control & $90.00^{\mathrm{a}}$ & - & $90.00^{\mathrm{a}}$ & - & $90.00^{\mathrm{a}}$ & - & $90.00^{\mathrm{a}}$ & - \\
\hline $\begin{array}{c}\text { CD } \\
(p=0.05)\end{array}$ & 2.52 & & 1.71 & & 1.93 & & 1.11 & \\
\hline
\end{tabular}

*Values are means of three replications. In a column, means followed by a common letter are not significantly different at $5 \%$ level by DMRT's

Table.3 Plant growth promoting activity of $P$. fluorescens isolates (Roll towel method)

\begin{tabular}{|c|c|c|c|c|}
\hline Isolates & $\begin{array}{c}\text { Root length } \\
(\mathbf{c m})\end{array}$ & $\begin{array}{c}\text { Shoot length } \\
(\mathbf{c m})\end{array}$ & $\begin{array}{c}\text { Germination } \\
\text { percentage(\%) }\end{array}$ & Plant vigour index \\
\hline $\mathbf{P f}_{\mathbf{1}}$ & $15.90^{\mathrm{c}}$ & $7.88^{\mathrm{b}}$ & $95.10^{\mathrm{bc}}$ & 2261.47 \\
\hline $\mathbf{P f}_{\mathbf{2}}$ & $15.11^{\mathrm{d}}$ & $7.32^{\mathrm{c}}$ & $94.65^{\mathrm{cd}}$ & 2122.99 \\
\hline $\mathbf{P f}_{\mathbf{3}}$ & $17.42^{\mathrm{b}}$ & $8.81^{\mathrm{a}}$ & $96.13^{\mathrm{ab}}$ & 2521.48 \\
\hline $\mathbf{P f}_{\mathbf{4}}$ & $11.80^{\mathrm{g}}$ & $5.23^{\mathrm{f}}$ & $90.78^{\mathrm{d}}$ & 1545.98 \\
\hline $\mathbf{P f}_{\mathbf{5}}$ & $18.23^{\mathrm{a}}$ & $9.12^{\mathrm{a}}$ & $97.21^{\mathrm{a}}$ & 2658.69 \\
\hline $\mathbf{P f}_{\mathbf{6}}$ & $14.65^{\mathrm{d}}$ & $6.82^{\mathrm{d}}$ & $93.14^{\mathrm{bc}}$ & 1999.71 \\
\hline $\mathbf{P f}_{\mathbf{7}}$ & $16.87^{\mathrm{b}}$ & $8.12^{\mathrm{b}}$ & $95.87^{\mathrm{ab}}$ & 2395.79 \\
\hline $\mathbf{P f}_{\mathbf{8}}$ & $12.54^{\mathrm{f}}$ & $5.96^{\mathrm{e}}$ & $91.29^{\mathrm{cd}}$ & 1688.86 \\
\hline $\mathbf{P f}_{\mathbf{9}}$ & $13.87^{\mathrm{e}}$ & $6.48^{\mathrm{d}}$ & $92.79^{\mathrm{cd}}$ & 1888.27 \\
\hline $\mathbf{P f}_{\mathbf{1 0}}$ & $13.01^{\mathrm{f}}$ & $6.10^{\mathrm{e}}$ & $92.11^{\mathrm{cd}}$ & 1760.22 \\
\hline $\mathbf{C o n t r o l}_{\mathbf{C D}(\mathbf{p = 0 . 0 5})}^{10.05^{\mathrm{h}}}$ & $4.56^{\mathrm{g}}$ & $73.57^{\mathrm{e}}$ & 1074.85 \\
\hline
\end{tabular}

*Values are means of three replications. In a column, means followed by a common letter are not significantly different at $5 \%$ level by DMRT's 
Table.4 Effect of various seaweed extracts on mycelial growth of $R$. solani by poisoned food technique under in-vitro condition

\begin{tabular}{|c|c|c|c|c|c|c|c|c|c|}
\hline \multirow[b]{2}{*}{ S.No } & \multirow[b]{2}{*}{ Seaweed extracts } & \multicolumn{8}{|c|}{ Mycelial growth of $R$. solani $(\mathrm{mm})$} \\
\hline & & $5 \%$ & $\begin{array}{c}\text { Percent } \\
\text { inhibition } \\
\text { over control }\end{array}$ & $10 \%$ & $\begin{array}{c}\text { Percent } \\
\text { inhibition } \\
\text { over control }\end{array}$ & $15 \%$ & $\begin{array}{c}\text { Percent } \\
\text { inhibition } \\
\text { over control }\end{array}$ & $20 \%$ & $\begin{array}{c}\text { Percent } \\
\text { inhibition } \\
\text { over control }\end{array}$ \\
\hline 1. & Chondrococcus homemanii & $50.35^{\mathrm{e}}$ & 44.05 & $36.57^{\mathrm{e}}$ & 59.36 & $27.58^{\mathrm{e}}$ & 69.35 & $15.30^{\mathrm{f}}$ & 83.00 \\
\hline 2. & Gracillaria corticata & $53.98^{\mathrm{d}}$ & 40.02 & $38.13^{\mathrm{e}}$ & 57.63 & $29.24^{\mathrm{d}}$ & 67.51 & $16.98^{\mathrm{e}}$ & 81.13 \\
\hline 3. & Sargassum wightii & $46.93^{f}$ & 47.85 & $31.60^{f}$ & 64.88 & $22.89^{\mathrm{g}}$ & 74.56 & $12.66^{\mathrm{g}}$ & 85.93 \\
\hline 4. & Padinatetrastomaticata & $47.41^{\text {ef }}$ & 47.32 & $33.48^{\mathrm{f}}$ & 62.80 & $24.47^{\mathrm{f}}$ & 72.81 & $13.57^{\mathrm{g}}$ & 84.92 \\
\hline 5. & Ulva lactuca & $61.48^{\mathrm{b}}$ & 31.68 & $47.15^{b}$ & 47.61 & $34.25^{\mathrm{a}}$ & 61.94 & $21.80^{b}$ & 75.77 \\
\hline 6 & Enteromorpha compressa & $56.50^{\text {cd }}$ & 37.22 & $41.89^{d}$ & 53.45 & $31.58^{\mathrm{c}}$ & 64.91 & $18.47^{\mathrm{d}}$ & 79.47 \\
\hline 7. & Enteromorpha intensalis & $58.57^{\mathrm{bc}}$ & 34.92 & $44.27^{\mathrm{c}}$ & 50.81 & $32.51^{\mathrm{c}}$ & 63.87 & $20.56^{\mathrm{c}}$ & 77.15 \\
\hline 8. & Control & $90.00^{\mathrm{a}}$ & - & $90.00^{\mathrm{a}}$ & - & $90.00^{\mathrm{a}}$ & - & $90.00^{\mathrm{a}}$ & - \\
\hline & CD $(p=0.05)$ & 2.96 & & 2.06 & & 1.53 & & 1.12 & \\
\hline
\end{tabular}

*Values are means of three replications. In a column, means followed by a common letter are not significantly different at 5\% level by DMRT's

Table.5 Antifungal activity of Sea weed extracts against $R$. solani under in-vitro condition

\begin{tabular}{|c|c|c|c|c|c|c|c|c|c|c|c|}
\hline \multirow[t]{3}{*}{ SI.NO } & \multirow[t]{3}{*}{ Sea weed extracts } & \multicolumn{10}{|c|}{ Inhibition Zone (mm) } \\
\hline & & \multicolumn{5}{|c|}{ Paper disc method } & \multicolumn{5}{|c|}{ Agar well method } \\
\hline & & $5 \%$ & $10 \%$ & $15 \%$ & $20 \%$ & Mean & $5 \%$ & $10 \%$ & $15 \%$ & $20 \%$ & Mean \\
\hline 1. & Chondrococcus homemanii & $31.78^{b}$ & $33.25^{\mathrm{b}}$ & $36.64^{b}$ & $37.29^{c}$ & 34.74 & $34.14^{\mathrm{b}}$ & $35.98^{\mathrm{b}}$ & $37.31^{\mathrm{c}}$ & $40.36^{\mathrm{b}}$ & 36.94 \\
\hline 2. & Gracillaria corticata & $29.10^{c}$ & $31.76^{\mathrm{c}}$ & $33.79^{c}$ & $35.12^{\mathrm{d}}$ & 32.44 & $31.94^{\mathrm{c}}$ & $33.57^{\mathrm{c}}$ & $35.78^{\mathrm{d}}$ & $38.24^{\mathrm{c}}$ & 34.88 \\
\hline 3. & Sargassum wightii & $35.42^{\mathrm{a}}$ & $37.37^{\mathrm{a}}$ & $40.78^{\mathrm{a}}$ & $42.58^{\mathrm{a}}$ & 39.03 & $37.40^{\mathrm{a}}$ & $39.24^{\mathrm{a}}$ & $40.47^{\mathrm{a}}$ & $43.29^{\mathrm{a}}$ & 40.10 \\
\hline 4. & Padinatetrastomaticata & $34.60^{\mathrm{a}}$ & $35.98^{\mathrm{a}}$ & $37.69^{b}$ & $39.71^{b}$ & 36.99 & $36.09^{a}$ & $37.21^{\mathrm{b}}$ & $39.28^{b}$ & $41.95^{\mathrm{ab}}$ & 38.63 \\
\hline 5. & Ulva lactuca & $22.24^{\mathrm{f}}$ & $23.89^{f}$ & $25.15^{\mathrm{f}}$ & $27.70^{\mathrm{g}}$ & 24.74 & $24.67^{\mathrm{e}}$ & $26.38^{\mathrm{e}}$ & $27.24^{\mathrm{g}}$ & $29.60^{f}$ & 26.97 \\
\hline 6. & Enteromorpha compressa & $27.47^{\mathrm{d}}$ & $28.91^{\mathrm{d}}$ & $30.80^{\mathrm{d}}$ & $32.71^{\mathrm{e}}$ & 29.97 & $28.49^{d}$ & $30.21^{\mathrm{d}}$ & $32.85^{\mathrm{e}}$ & $35.46^{\mathrm{d}}$ & 31.75 \\
\hline 7. & Enteromorpha intensalis & $25.09^{\mathrm{e}}$ & $26.91^{\mathrm{e}}$ & $28.34^{\mathrm{e}}$ & $30.69^{f}$ & 27.75 & $26.12^{\mathrm{e}}$ & $27.78^{\mathrm{e}}$ & $29.45^{\mathrm{f}}$ & $32.04^{\mathrm{e}}$ & 28.84 \\
\hline \multirow[t]{2}{*}{8.} & Control & $0.00^{\mathrm{g}}$ & $0.00^{\mathrm{g}}$ & $0.00^{\mathrm{g}}$ & $0.00^{\mathrm{h}}$ & 0.00 & $0.00^{\mathrm{t}}$ & $0.00^{\mathrm{g}}$ & $0.00^{\mathrm{h}}$ & $0.00^{\mathrm{g}}$ & 0.00 \\
\hline & $\mathrm{CD}(\mathrm{p}=\mathbf{0 . 0 5})$ & 1.00 & 1.41 & 1.88 & 1.05 & & 1.49 & 1.71 & 1.09 & 1.80 & \\
\hline
\end{tabular}

*Values are means of three replications. In a column, means followed by a common letter are not significantly different at $5 \%$ level by DMRT's 
Generally all sea weeds extracts inhibited the mycelia growth of pathogen in the present study. Sargassum wightii (Brown algae) at $20 \%$ conc. exhibited the highest level of inhibition of $R$. solani. This statement has been confirmed. by several workers. Sultana et al., 2007, reported that brown, green, red sea weeds were highly effective against $R$. solaniin vitro and in vivo conditions. There are several workers have been reported on the efficacy of sea weed extracts against fungal pathogens (Norrie et al., 2002: Jayaraj et al., 2008). This may be due to higher levels and early accumulation of phenolics and phytoalexins (Garcia- Mina et al., 2004). The above results lend supports to the present findings.

\section{References}

Ammirato, P. 1986. Morphogenesis and clonal propagation. In: Plant tissue culture and its agricultural application. (Eds) Withers, L, Alderson P.Butterworth, London. 21-47.

Dennis, C and j. Webster. 1971. Antagonistic properties of species groups of Trichoderma I production of nonvolatile antabiotics. Trans. Brit. Mycol. Soc. 57: 25-39.

Garcia-Mina, J.M., Antolin, M.C., SanchezDiaz, M. 2004. Metal humic complexes and plant Micro- nutrient ptake: a study based on different plant species cultivated in diverse soil types. PlantandSoil.258: 57-68.

Gupta, S.K., P.P. Gpta and C.D.Kaushik., 2001. Changes in leaf peroxides, polyphenol oxidase, catalase and catalase and total phenols due to Alternaria leaf blight in Braisica species. Indian J. Mycol. Plant Pathol. 25:175180

Jayaraj, J., Wan, A., Rahman, $\mathrm{M}$ and Punja, Z.K. (2008), Seaweed extract reduces foliar fungal disease on carrot. Crop
Protection27: 1360-1366.

Jeffrey Norrie, Gustavo Hernandez, Rosalba Mireya, Fernando and Maria Alberto., 2014. Effect of liquid sea weed extracts on growth of tomato seedlings (Solanum lycopersium L.) Journal of Applied Phycology. 26(1); 619-628.

King, E.O, Wood, M.K and Randey, D.E. 1954. Two simple media for the demonstration of pyocyanin and luorescin. Jornal of Laboratory Clinical Medicine.44(2); 301-307

M. Seema and N.S. Devaki., 2012. In vitro evaluation of biological control agents against Rhizoctonia solani. Journal of Agricultural technology.8(1):233-240.

Norrie, J., Branson, T., Kethley, P.E. 2002. Marine plants extract impact on grape yield and quality. Actahorti.(ISHS) 594: 315-319.

Ongena, M.F.P, Daayf., N, Jaques., T.C, Thorart., P, Benhamou., M, Pauliz, R.K. Cornelis and Belinger. 1999. Production of cucumber against Pythium root rot by Fluorescent pseudomonads: predominant role of induce resistance over siderosphores and antibiotics. Plant Pathology.48: 66-76.

Pandey, A., P. Trivedi., B.Kumar and L.S.Thorarat., 2006. Characterization of phosphate solubilizing and antagonistic strain of Pseudomonas putida isolated from a sbalphine location in the Indian Central Himalayan. Curr. Microbial.48:66-76.

Rathore S.S., Chaudhary, D,R., Boricha, N.G., Ghosh, A., Bhatt, B.P., Zodapes, S.T and patolia, J.s., 2009. Effect of sea weed 0065 tract on the growth, yield nutreient uptake of Soybean (Glycine max) under rainfed conditions, South African Journal of Botany.75: 351-355.

Reddy, B.P., K.R.N. Reddy., B.P.Subba Rao and K.S. Rao., 2008.Efficacy of antimicrobial metabolites of Pseudomonas fluorescens against rice 
fungal pathogens. Curr.Trends Biotechnol.Pharmacy.2: 178-182.

Saha, B.P., Saha. K., Mukherjee, P.K, Mandal, S.C. and Pal, M. (1995), Antibacterial activity of Leucaslavandulae foliarees, Indian Drgs. 32;402-404.

Schmitz, H. 1930. Poisoned food technique. Indust. Engin. Chem. Analyst, 361-363.

Sharma, P., Kulshrestha, G., Gopal, M and Kadu, L.N. 2004.Integrated management of chilli die- back and anthracnose in Delhi region.IndianPhytopath.57(4): 427-434.

Sultana, V., Ehteshamul, S and Ara, J. 2007. Management of root diseases of soybean and tomato with sea weeds application. Phytopathology.97.

Suthinraj.T., K. Hanegraff and H. Ann Suji., 2016. Biochemical characterization of a Brown sea weed algae and its efficacy on control of rice sheath blight caused by Rhizoctonia solani Kuhn. International Journal of Tropical Agriculture. 34(2): 429-439.

Thongson, C., Davidson, P.M.,
Mahakarrchanakul, W., Weiss, J. (2004), Antimicrobial activity ofultrasound assisted solvent - extracted species. Letters Appl. Microbial. 39: 401-406.

Velazhahan, R., R. Samiyappan and P. Vidhyasekaran., 1999. Relationship between antagonistic activities of Pseudomonas fluorescens isolates against Rhizoctonia solani and their production of lyticenzymeszeitscrift fur pflanzenkran kheiten and pflanzenschutz.106: 244-250.

Vallinayagam, K., Arumugam, R., Kannan, R.R., Thirumaran, $\mathrm{G}$ and Anantharaman, P. (2009), Antibacterial activity of some selected seaweeds from pudumadam coastal region. Glob. J. Pharmacol. 3: 50-52.

Vincent, J,M. 1927. Distortion of fungal hypha in the presence of some inhibitors, Nature.159-850.

Suryadi, Y., D.N. Susilowati., E.Riana and M.R. Mubarik., 2013. Management of rice blast disease (Pyricularia oryzae) using formulated bacterial cinstorium. Plant Science. 25(5): 349-357.

\section{How to cite this article:}

Anandeeswari, D. and John Christopher, D. 2020. Invitro Evaluation of Sea Weed Extracts and Bio-control Agent against Rhizoctonia solani causing Rice Sheath Blight Disease. Int.J.Curr.Microbiol.App.Sci. 9(09): 799-808. doi: https://doi.org/10.20546/ijcmas.2020.909.101 